\begin{tabular}{|c|c|c|}
\hline & \begin{tabular}{c} 
International Journal of Current Research in \\
Biosciences and Plant Biology \\
\hline
\end{tabular} \\
EXCELLENT \\
PUBLISHERS
\end{tabular}

\title{
Biotechnological approaches in pesticide remediation - A Review
}

\author{
Ravi Teja Mandapaka*
}

\begin{abstract}
Senior Research Fellow, Centre for Gender Studies, Nutritional Security and Urban Agriculture, National Institute of Agricultural Extension Management (MANAGE), Hyderabad, Telangana 500 o30, India

*Corresponding author e-mail: ravitejamandapka@gmail.com
\end{abstract}

\begin{tabular}{|c|c|}
\hline Article Info & ABSTRACT \\
\hline $\begin{array}{l}\text { Date of Acceptance: } \\
24 \text { November } 2020\end{array}$ & \multirow{3}{*}{$\begin{array}{l}\text { Bioremediation is a process of breaking down the nutrients using biological processes } \\
\text { under optimal environmental conditions. Current review will focus on the various types } \\
\text { of bioremediation, the various technologies surrounding it, and their advantages and } \\
\text { disadvantages. Focusing on the application of nutrients alone will not reap expected } \\
\text { scientific benefits, but, a combination of applying nutrients and microbial } \\
\text { augmentation will be more advantageous. Bioremediation, also known as } \\
\text { environmental biotechnology, is a form of biotechnology that seeks to reduce the } \\
\text { environmental pollutants, which has become one of the best alternatives that } \\
\text { counteracts the use of products and physical-chemical processes directed to the same } \\
\text { end. In a real world scenario, hydrocarbons are sensitive to biodegradation, some more } \\
\text { easily than others. When a spill occurs in the water, the continuous movement caused } \\
\text { by wind and waves produces mixtures of compounds on a microscopic scale. This is } \\
\text { where bacteria such as pseudomonas, corynebacteria, mycobacteria, seaweed and } \\
\text { yeasts begin to process the degradation of those aliphatic and aromatic components, } \\
\text { which can be oxidized by microorganisms. In this review, the author discussed } \\
\text { importance of focusing environmental policies towards achieving sustainable } \\
\text { development in individual nations. There is also a serious need of managing natural } \\
\text { resources rationally and responsibly towards preventing harmful consequences that } \\
\text { otherwise affect our environment. The current review also stresses on the very } \\
\text { technologies and various steps towards the manipulating processes of bioremediation } \\
\text { in order to make it more scientifically and financially available for addressing the } \\
\text { contaminated environment. }\end{array}$} \\
\hline Keywords & \\
\hline $\begin{array}{l}\text { Biodegradation } \\
\text { Bioremediation } \\
\text { Microorganisms } \\
\text { Pesticides } \\
\text { Phytoremediation }\end{array}$ & \\
\hline
\end{tabular}

\section{Introduction}

The use of biotechnological remedies for addressing environmental deterioration has made a remarkable beneficial impact on the lives of human population and other species. Pesticides, which are varied chemical substances that act on harmful pest organisms, can have huge tending damage to the crops. Continual use of these harmful pesticides may result in the accumulation in agricultural produce. Pesticides are mainly classified based on their toxicity and biodegradable nature. Nearly one third of the world's agricultural production is lost every year which is more than two million tons, despite the pesticide usage. In India alone, the aforementioned harmful organisms cause crop loss worth more than Rs 6000 crores annually, of which, $33 \%$ is due 
to weeds, $26 \%$ by diseases, $20 \%$ by insects, $10 \%$ by birds and rodents and the remaining $11 \%$ due to other factors (Rajendran, 2003).

The indisputable need to remedy the impact of industrial and domestic pollution, prompted the creation of new technologies that are oriented towards the detoxification and disappearance of polluting substances, in contrast to the traditional waste disposal approach. The term remediation was used for the first time in the early 8os, referring to the remediation techniques that applied physicalchemical strategies that reversed or avoided the damage caused to soils, as a result of the constant contamination. The use of microorganisms in bioremediation was carried out for the first time by the American scientist George M. Robinson, who set out to experiment with some microbes in containers contaminated with oil. Robinson thought that the environment could be decontaminated using microorganisms. From this experience to the present time, much has been achieved.

The remediation techniques using biology thus take advantage of the potential of living organisms, microorganisms or vegetation to degrade pollutants naturally. Bioremediation thus broadly refers to all those biotechnological processes aimed at achieving environmental sanitation, making use of the metabolic potentials of microorganisms such as bacteria and fungi, to eliminate contaminating substances or agents in water and soil. This is because these microscopic organisms and also some plants, have the ability to naturally transform various harmful and toxic compounds, to reverse this condition.

\section{Research background}

The pesticide usage in agriculture is an important concern due to the risks it poses on the environment and in turn on the health of humans, animals and plants. Considering the Indian scenario, close to 234 pesticides are registered on crops unlike more than 20,000 products that are registered under United States Environmental Protection Agency (USEPA). It is estimated that nearly 700 million Indians have zero access to a clean toilet, and close to 1,00o children are victims of diarrhoea every single day. Injurious effects of contaminants on the micro-organisms will directly lead to losses in biodiversity. In one such study, it was observed that $98 \%$ of the pesticides imported were classified as acutely toxic for fish and crustaceans and $73 \%$ of those were classified as acutely toxic for amphibians (Elba et al., 2014).

Research conducted in India reported that, alachlor, aldrin, atrazine, carbofuran, chlordane, DDT, HCB, heptachlor, lindane, methoxychlor, simazine are the most commonly found pesticides (Ali and Jain, 2009). Pesticides such as DDT and Dieldrin keep stay the course in the environment for longer periods and eventually get accumulated in the food chains after decades. On the other hand, organophosphates like malathion, parathion, diazinon, fenthion are the most frequently used and the most easily biodegradable ones. On the other hand, pesticides like atrazine and simazine, do not have an easily biodegradable nature. (Aberdeen, 1993; Kannan et al., 1994).

One good approach to get rid from these harmful pollutants is to completely destroy them, or at least to transform them to harmless substances. Some technologies that have been used are hightemperature incineration and various types of chemical decomposition. They may be very effective but have several drawbacks. They are technologically complex, have unaffordable prices for small-scale application, and lack public acceptance. Bioremediation is one feasible option offering a unique possibility to either damage completely or proffer harmless many contaminants through naturally occurring biological activities. (Vidali, 2001).

Bioremediation is very useful and detoxifies the environment and fields. It is aimed at reducing the levels of pollutants to undetectable, nontoxic or acceptable levels. It is a new advancement in the effective management of wastes, which aids the use of microorganisms to wipe out pollutants from the site of infection or contamination. The Environmental Protection Agency says bioremediation is a "treatment that uses naturally occurring organisms to break down hazardous substances into less toxic or non-toxic substances".

\section{Advantages of bioremediation}

The different methods used by bioremediation seek to completely eliminate contamination, although it is not always achieved in its entirety; it is not about 
transferring contamination from one physical state to another, as it happens in other treatments that use this type of technique. Its use does not cause prominent risks in the environment. The basic inputs that are used are products that the same environment makes them as part of their natural process, therefore, it is a very economic option that would reduce the costs of public budgets.

\section{Methods of bioremediation}

\section{Mycoremediation}

Mycoremediation involves the use of fungi to decontaminate the affected areas, specifically, through the vegetative body (mycelia). The mycelia are the group of non-visible filamentary ducts that are part of the structure of the fungus, which are commonly known for the function of decomposing organic matter in any ecosystem. This ability to decompose organic matter gives the mycelium the ability to transform hydrocarbons into organic fertilizer, with criteria of economy.

\section{Phytoremediation}

Through this method an attempt is made to solve the damage caused to the environment by using the properties of the plants. For example, they can absorb and then degrade contaminants from the soil; this would be a substitute measure for the common way of depositing the harmful materials in an underground place that has been determined suitable for that purpose, which at the same time would reduce costs. The substances that could be eliminated include pesticides, solvents, hydrocarbons, as well as remains of precious metals that, in general, are toxic substances.

\section{Bioventing}

Bioventing is the decomposition by microorganisms of the toxic materials that have contaminated the water. It is based on a process of stimulation of the existing bacteria in the affected area, so that the hydrocarbons are biodegraded. Bioventing improves the indigenous bacterial activity and initiates the natural in situ biodegradation with the help of oxygen flow into an unsaturated area. Bioventing majorly degrades adsorbed fuel residues and volatile organic compounds.

\section{Bioleaching}

It consists of the extraction process of some metals that are embedded in the minerals, without making use of cyanide, as is customary in the traditional method of leaching. These new practices are used more and more in mining activity, because they have less ecological impact due to the reduction of soil contamination.

\section{Land cultivation}

It is about decontaminating the soil off the substances such as slurry, sediments or toxic sludge, incorporating them into the soil that has been removed several times in order to create a new composition. In short, the agricultural crops serve as a mechanism for cleaning or decontaminating the surface soil. With this technique, the presence of hydrocarbons and pesticides can disappear, since, once the soil is mixed and ploughed, which is contaminated with the soil in good condition, its oxygenation is increased, causing the microbial flora to be stimulated and their reproduction accelerated.

\section{Bioreactor}

This method is frequently used to transform contaminated waters produced by agricultural activity into organic fertilizers. It incorporates the same mechanism of decomposition that occurs in a home composting system, but with a higher level of complexity, which is applied in industrial activities. It consists of generating chemical processes from the contact of microorganisms with chemical agents, controlled either with the presence of oxygen or without oxygen.

\section{Composting}

This is a method as old as agriculture itself, which is nothing more than turning organic waste into organic fertilizer i.e. natural fertilizer, which can then be used to replenish the nutrients in the soils that have been affected by the excess of activities agricultural or erosion processes. The process is based on applying decomposition techniques in organic matter, either with a large amount of oxygen or without using this element. Because of its simplicity, it is a very popular method in the fields worldwide. The soil is added with nutrients mixed 
towards increasing aeration and activating indigenous microorganisms. Usually, we do composting in a separate vessel and upon completion, it is put into the soil. Composting, in fact, is a cost-effective method towards remediation of soils.

\section{Bio-augmentation}

It is a method of inoculation of previously modified microbial strains to efficiently accelerate the decontamination of soils and waters; the same bacteria that are present in the contaminated place may be able to clean or restore it, so increasing the number of these bacteria is the key to achieving the goal of biological remediation. The application of this method is very common to treat wastewater from localities.

\section{Rhizofiltration}

The basic principle of phytoremediation (use of plants) is used, using the roots to filter the water and clean it off the toxic elements or harmful agents. The plants used in these filtering processes are grown hydroponically (the nutrients are not provided by the soil, but a serum with enriched content).

\section{Biostimulation}

It consists of taking advantage of the benefits of "bioremediating" bacteria that are in a polluted environment. It involves modifying the environment to stimulate these bacteria so that they can develop to their maximum capacity to detoxify and restore. The affected environment can be modified by increasing the amount of nutrients that favour the growth of these useful microscopic organisms; also with the inoculation of genetically modified strains, as is done in biostimulation.

\section{Disadvantages of bioremediation}

Although these are techniques or methods that apparently do not have a higher level of complexity, many of those who apply them do not do it correctly. Therefore, the consequences can become as polluting as the problem that was trying to be solved. For example, if the cycles are not completed, very serious changes are generated in the metabolism of the microorganisms that are being stimulated, which possibly cannot be remediated later. Each technique used must have a prudential time of application in which the expected results can be seen. In many cases of bioremediation application it is difficult to calculate the period of time that is required for the total development of the process, being able to generate more costs than those considered if the monitoring, control and extension stages are lengthened. When the separation technique is executed, the waste that is generated must be treated or disposed off immediately, which causes costs to increase and other processes to be carried out.

\section{Bioremediation in a real world scenario}

Hydrocarbons are sensitive to biodegradation, some more easily than others. When a spill occurs in the water, the continuous movement caused by wind and waves produces mixtures of compounds on a microscopic scale. This is where the predominant bacteria such as pseudomonas, corynebacteria, mycobacteria, as well as seaweed and some yeasts, begin to process the degradation of those aliphatic and aromatic components, which can be oxidized by microorganisms. There are many cases of natural disasters that have occurred worldwide, as a result of oil activity. Generally oil spills are absorbed by the soil and consequently the water layer is affected. In the Deepwater Horizon disaster (2010, Gulf of Mexico), where an oil rig exploded that produced the worst spill in history, bioremediation techniques were applied when it was verified that the spilled oil had bacterial activity.

While some human beings, either privately or corporately, act irresponsibly by consciously or unconsciously damaging the environment, contaminating indiscriminately, affecting the different terrestrial and aquatic ecosystems, extinguishing plant animal species; others work tirelessly looking for solutions to remedy and raise awareness about the consequences that these damages can have on our planet. There has been an intriguing interest in organic carriers which are basically waste products of industries related to food and agriculture. The various functional groups generate in these respective industries are said to have an advanced effect on the degree/rate of colonization by the microorganisms. In bioremediation, carries like loofah sponge and 
corncob were used to success in the in situ lines. On the other hand, carriers like bagasse, sawdust, expanded perlite etc. are known to have success in the ex situ lines.

Without an iota of doubt, one can, from a scientific perspective, mention about the impact of pesticides on the fertility of soil. Contaminated soils and polluted lands have attracted much attention as they have a direct impact on human health and the habitant ecosystem. Advanced scientific approaches for bioremediation today have a large scope for the remediation of pesticide effected or damaged soils. Environmental policies should be aimed at achieving the sustainable development of each country, which implies that the use of natural resources be managed rationally and responsibly, from the point of view of prevention and from the application of new technologies that contribute to correcting the harmful consequences that affect our environment.

\section{Conflict of interest statement}

Author declares that there is no conflict of interest.

\section{Acknowledgement}

The author acknowledges Dr. Lakshmy Ramachandran and Dr. Srikanth Mekala for their encouragement and support.

\section{References}

Aberdeen, I., 1993. Litigation over dieldrin in Victoria. Agricultural Science May, 42-5.

Ali, I., Jain, C. K., 2009. Groundwater contamination and health hazards by some of the most commonly used pesticides, http://www.iisc.ernet. in/currsci/nov251998/articles17.htm.

Balaji, V., Arulazhagan, P., Ebenezer, P., 2014. Enzymatic bioremediation of polyaromatic hydrocarbons by fungal consortia enriched from petroleum contaminated soil and oil seeds. J. Environ. Biol. 35, 521529.

Carter, M. R., Gregorich, E. G., 2007. Soil Sampling and Methods of Analysis, $2^{\text {nd }}$ Edn, Canadian
Society of Soil Science, pp.28-45.

Das, N., Chandran, P., 2011. Microbial degradation of petroleum hydrocarbon contaminants: An overview. Biotechnol. Res. Inter. 2011, Article ID 941810, 1-13.

Dzionek, A., Wojcieszyńska, D., Guzik, U., 2016. Natural carriers in bioremediation: A review. Elect. J. Biotechnol. 19(5), 28-36.

Elba de. La., Cruz, Bravo-Durán V., Ramírez, F., Castillo, L. E., 2014. Environmental hazards associated with pesticide import into Costa Rica, 1977-2009. J. Environ. Biol. 35, 43-55.

Federal Remediation Technologies Roundtable. 1994. Untitled Composting Figure. Remediation Technologies Screening Matrix and Reference Guide, Version 3.0. www.frtr.gov/matrix2/ section4 July 17, 2000.

Gavrilescu, M., 2005. Fate of Pesticides in the Environment and its Bioremediation, pp.20-12.

Hussain, S., Siddique, T., Arshad, M., Saleem, M., 2009. Bioremediation and phytoremediation of pesticides: Recent advances. Crit. Rev. Env. Sci. Tech. 39, 843-907.

Kandpal, V., 2014. Biopesticides. Int. J. Environ. Res. Dev. 4, 191-196.

Kannan, K., Tanabe, S., Williams, R. J., Tatsukawa, R., 1994. Persistant organochlorine residues in foodstuffs from Australia, Papua New Guinea and the Solomon Islands: contamination levels and dietary exposure. Sci. Total Environ. 153, 29-49.

Kookana, R. S., Aylmore, L. A. G., 1994. Estimating the pollution potential of pesticides to ground water. Austr. J. Soil Res. 32, 1141-55.

Rao, M.A., Scelza, R. Scotti, R., Gianfreda, L., 2010. Role of enzymes in the remediation of polluted environments. J. Soil Sci. Plant Nutr. 10(3), 333 353.

Singh, R., Singh, P., Sharma, R. 2014. Microorganism as a tool of bioremediation technology for cleaning environment: A review. Proc. Int. Acad. Ecol. Environ. Sci. 4(1), 16.

Sivaramanan, S., 2014. Biodegradation of saw in plant fertilizer. Res. J. Agri. For. Sci. 2(2), 1319.

USEPA, 1997. Treatment Technologies for SITE Cleanup: Annual Status Report, Ninth Edition. EPA/542/R-99/o01. Office of Solid Waste and Emergency Response, Technology Innovation Office. Washington, DC.

\section{How to cite this article:}

Ravi Teja, M., 2020. Biotechnological approaches in pesticide remediation - A Review. Int. J. Curr. Res. Biosci. Plant Biol. 7(12), 16-20. doi: https://doi.org/10.20546/ijcrbp.2020.712.003 